\title{
Submarine and coastal karstic groundwater discharges along the southwestern Mediterranean coast of Turkey
}

\author{
C. Serdar Bayari • N. Nur Ozyurt • Mehmet Oztan • \\ Yalin Bastanlar • Guzden Varinlioglu • \\ Hayati Koyuncu • Haldun Ulkenli • Serdar Hamarat
}

Stable isotope data suggest a range of mean recharge area elevations extending from the coast to more than $1,000 \mathrm{~m}$ inland. In many of the SGDs, the FEMs are characterized by tritium-based residence times ranging from recent to several decades. Hypothetical geochemical calculations of mixing between freshwater and seawater end members reveal that more than $45 \%$ of freshwater contribution is required for karst development in the SGDs. Models suggest a threshold $\mathrm{pH}$ of 7.6 or lower for the carbonate rock dissolution.

Keywords Submarine groundwater discharge .

Hydrochemistry · Karst · Turkey · Environmental isotopes
Received: 1 August 2009 / Accepted: 27 October 2010

Published online: 26 November 2010

(C) Springer-Verlag 2010

Electronic supplementary materialThe online version of this article (doi:10.1007/s10040-010-0677-y) contains supplementary material, which is available to authorized users.

\section{S. Bayari (®)}

International Research and Application

Center For Karst Water Resources,

Hacettepe University, Ankara, 06800, Turkey

e-mail: serdar@hacettepe.edu.tr

N. N. Ozyurt • M. Oztan

Department of Geological Engineering,

Hydrogeological Eng. Section,

Hacettepe University, Ankara, 06800, Turkey

N. Ozyurt

e-mail: nozyurt@hacettepe.edu.tr

M. Oztan

e-mail: moztan@hacettepe.edu.tr

Y. Bastanlar $\cdot$ H. Ulkenli $\cdot$ S. Hamarat

Underwater Research Society, Cave Research and Diving Group,

Tiflis Cad. 54/2 Cankaya, Ankara, 06550, Turkey

Y. Bastanlar

e-mail: yalinb@yahoo.com
H. Ulkenli

e-mail: ulkenli@yahoo.com

S. Hamarat

e-mail: serdar.hamarat@karel.com.tr

G. Varinlioglu

Department of Interior Architecture and Environmental Design, Bilkent University, Ankara, 06800, Turkey

G. Varinlioglu

e-mail: guzden@bilkent.edu.tr

H. Koyuncu

Jeodijital Inc,

Cukurambar Mah. 44. Cadde, No 2/1 Cankaya , Ankara, 06520,

Turkey

H. Koyuncu

e-mail: hayatik@jeodijital.com 


\section{Introduction}

Submarine groundwater discharges (SGDs) are regarded as a potential water resource where other means of accessing potable water is practically impossible. Existence of SGDs has been known since the early historical times at sites located mainly in the Mediterranean Sea, the Black Sea and the Persian Gulf (e.g. SCOR and LOICZ 2006; Fleury et al. 2007; Bakalowicz et al. 2008). In the modern scientific era, the importance and peculiar properties of SGD were noted for the first time in the late 1960s by the pioneering study of Kohout (1966). The efforts on SGD research have intensified since the studies by Moore (1996) and Younger (1996), in which SGD is regarded as a potentially important source of nutrient influx to the marine environment. The number of studies on SGDs has increased considerably (e.g. Taniguchi et al. 2002). Several review papers summarize the state-of-the-art developments in SGD science (e.g. SCOR and LOICZ 2006; Burnett et al. 2006). On the other hand, the need for increasing involvement of hydrogeologists in current SGD research has also been emphasized recently (e.g. Kazemi 2008). Nevertheless, the current literature involves a number of studies on the hydrogeologic aspects of SGD. Some of these studies focus on karstic SGDs, particularly in the Mediterranean Sea region, where a considerable part of the coastline is formed by carbonate rocks possessing substantial karstification (e.g. Bakalowicz et al. 2008; Mijatovic 2007). Among these, the southern coastline of Turkey, where carbonate rocks involving remarkable SGDs deserves special attention. While parts of the Turkish Mediterranean Coast with SGDs have been subject to hydrogeologic research during the last few decades (e.g. Günay 1971; Kohout 1977; Elhatib 1987, 1992; Elhatib and Günay 1998; Bayari and Kurttas 2002; Hamarat et al. 1998; Bakalowicz et al. 2008), systematic determination of the SGDs along the karstic coastlines (e. g. Bayari and Kurttas 2002; Bayari et al. 2007; Oztan 2004; Oztan et al. 2004) has rarely been attempted. There is an increasing need for such studies because of the growing demands for potable water in coastal zones as the result of ever intensifying human activities. Recent findings also imply that karstic SGDs may have an important role in submarine ecosystems (e.g. Meric et al. 2008).

This study involves a systematic survey of the SGDs along the southwestern Mediterranean coast of Turkey where most of the coastline is formed by karstified carbonate rocks with considerable extension inland. In this context, about $120 \mathrm{~km}$ of coastline has been surveyed in detail by systematic diving efforts at depths ranging down mostly to $30 \mathrm{~m}$ below sea level (bsl). The SGDs discharging from coastal and submarine caves and from the impenetrable fracture zones have been detected based on the temperature and turbidity anomalies caused by the mixing between groundwater and seawater. The physical (i.e. temperature and specific conductance), chemical (i.e. major ion composition) and isotopic (i.e. oxygen-18, deuterium and tritium) data collected from the detected SGDs have been used to characterize the temporal dynamics of SGDs.

\section{Study area}

\section{Location, morphology and climate}

The study area, which is located in the southwestern Mediterranean coast of Turkey (Fig. 1), comprises a $\sim 120$ $\mathrm{km}$ long coastline that extends between the Yali Horn $\left(36^{\circ}\right.$ $\left.13^{\prime} 48.47^{\prime \prime} \mathrm{N}, 29^{\circ} 21^{\prime} 17.17^{\prime \prime} \mathrm{E}\right)$ in the west and the Yardimci Horn $\left(36^{\circ} 12^{\prime} 35.84^{\prime \prime} \mathrm{N}, 30^{\circ} 24^{\prime} 17.57^{\prime \prime} \mathrm{E}\right)$ in the east (Fig. 2). The inland morphology is characterized by the rugged and mountainous landscape of the Taurus Mountains range where the elevation is more than $3,000 \mathrm{~m}$ above sea level (asl) at locations about $30 \mathrm{~km}$ beyond the coastline. Except for the coastal plains, formed in tectonic collapse zones (i.e. Esencay and Finike-Kumluca Plains on the west and east, respectively), the elevation along the coastline increases abruptly from sea level to around $1,000 \mathrm{~m}$ asl or more within a distance of several kilometers. This mountainous landscape is dominated mainly by the Mesozoic-aged carbonate rocks possessing extensive karst development. A Mediterranean type climate characterized by hot dry summers and mild wet winters prevails in the study area. Precipitation that occurs mainly between November and April is in the form of rainfall along the coastal zone, whereas snowfall is observed roughly above $1,000 \mathrm{~m}$ asl. Many of the precipitation events have orographic character because of the steep topographic gradient created by the mountain belt in front of the storm tracks originating from the Atlantic Ocean and/or Mediterranean Sea. Because the study area spreads over a large elevation range, rainfall and snow dominate at lower and higher elevations, respectively. Similarly, the amount of precipitation varies both by the altitude and by the local orographic barriers. The long-term mean annual precipitation is around 850 $\mathrm{mm} /$ year along the coastal zone and reduces to $500 \mathrm{~mm} /$ year in the intra-mountainous plains (e.g. Elmali Plain, see Fig. 2) located around $1,000 \mathrm{~m}$ asl. Yet, the precipitation at higher elevations is estimated to be around $1,200 \mathrm{~mm} /$ year. The mean annual air temperatures along the coastal zone and in the intra-mountainous plains are 20 and $13^{\circ} \mathrm{C}$, respectively. A temperature lapse rate of $0.7^{\circ} \mathrm{C} / 100 \mathrm{~m}$ is inferred for the study area.

\section{Regional geology}

The present geological structure of the study area, a part of the Alpine-Himalayan Orogenic Belt, was formed by the closure of the southern branch of the Neo-Tethys Ocean during the late Miocene. Because of this tectonic process, several carbonate platforms, once nested in the Neo-Tethys Ocean, have been stacked in a narrow zone that forms the present Taurus Mountains range in southwestern Turkey. The rock units belonging to carbonate platforms constitute two allochthonous and one autochthonous succession (Senel 1997a, b). During the early Miocene, the Western (Lycian) Nappes in the west and the Eastern (Antalya) Nappes in the east thrusted over the Beydaglari autochthonous, located in the center of study area, to form this part of the Taurus Mountain Belt (see 


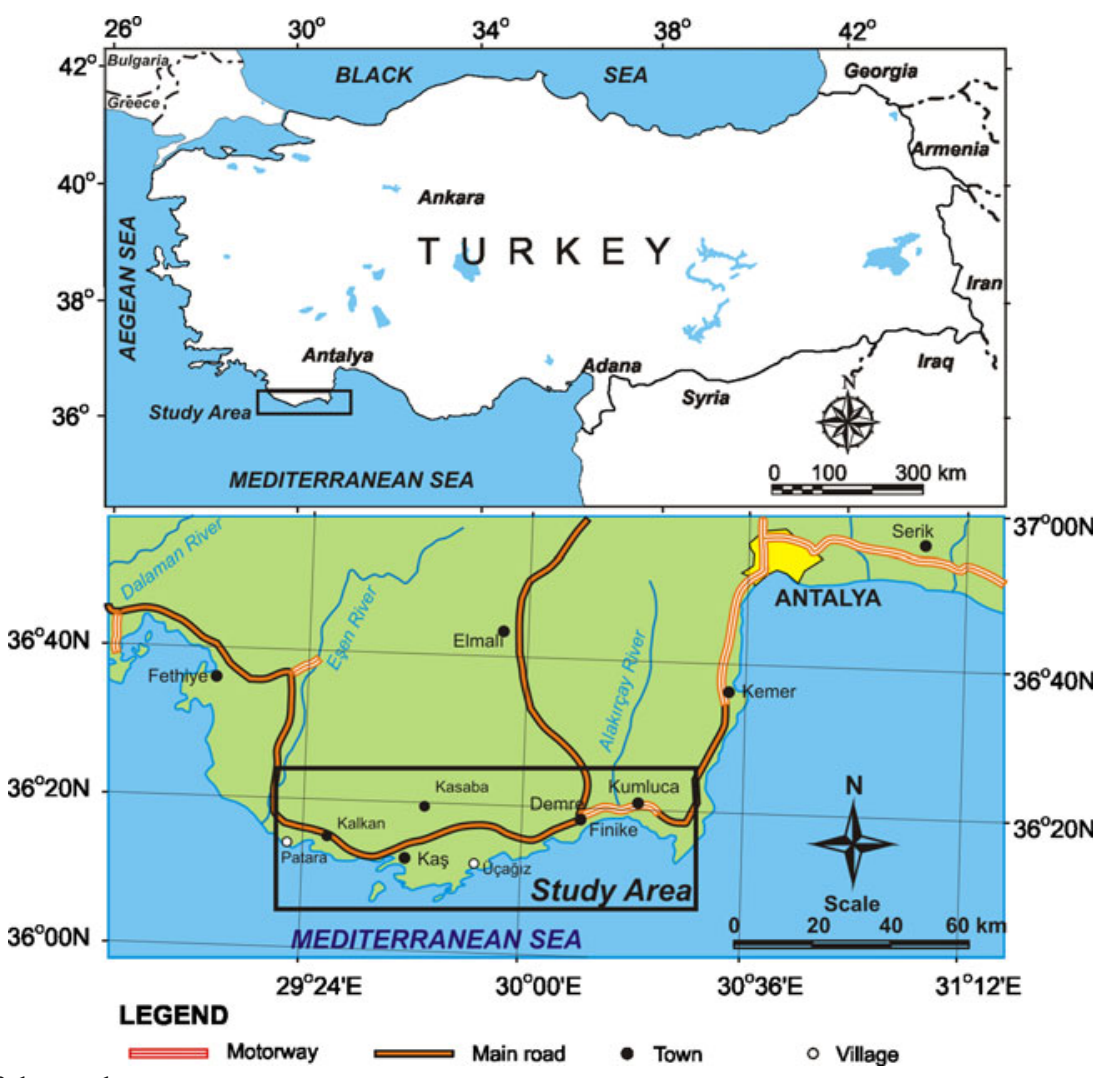

Fig. 1 Location map of the study area

Fig. 2). Since then, the continuing closure between AfroArabian Plates to the south and the Eurasian Plate to the north has resulted in an on-going uplift of the mountain belt. The Western Nappes comprise mainly Lias-Late Cretaceous-aged neritic limestone, which is overlain unconformably by late Paleocene-middle Eocene-aged thick breccia composed of limestone, sandstone, conglomerate, basalt and spilite. The Eastern Nappes comprises three distinct nappe units. The Alakircay Nappe includes late Anisian-Norian-aged conglomerate, sandstone, chert, spilit and basalt. The overlying Tahtalidag Nappe is made mainly of Resian-late Cretacesous-aged limestone. Both nappe sequences are overlain by Tekirova ophiolite nappe. The Beydaglari autochthonous sequence starts at the bottom with Late Cretaceous-aged dolomitic limestone and dolomite. This sequence is overlain unconformably with the Eocene-aged neritic limestone in the coastal zone. In the inner part, the Late Cretaceous carbonates are overlain by Burdigalian-aged limestone, sandstone, claystone and siltstone. A sequence of late BurdigalianLangian-aged sandstone, claystone and siltstone is observed in the intra-mountainous plains. The PlioQuaternary deposits are observed in the intra-mountainous and coastal plains, which have been formed due to extensional tectonics that followed the primary mountain building period in the late Miocene.

The Late Cretaceous-aged carbonate rocks belonging to the autochthonous succession dominate almost in the entire extent of the coastline where many of the SGDs detected in this study are located. A limited number of
SGDs have been found to discharge from the Western and Eastern nappes.

\section{Regional hydrogeology}

In view of the regional hydrogeology, the carbonate rocks of autochthonous and allochthonous sequences form the karstic aquifers, whereas the coarse-graded clastic units belonging to Mio-Pliocene and Quaternary sequences constitute the granular (non-karstic) aquifers. The productive aquifers of the Quaternary deposits lying in the coastal and inland plains are fed both by the surrounding karstic units and by the local precipitation. The welldeveloped karstic aquifers with mostly naked outcrops allow fast percolation of precipitation so that the surface drainage by streams is almost negligible. Because of the extensive karst development, the groundwater in the karstic terrain is difficult to access by deep wells (e.g. $>100 \mathrm{~m}$ ), particularly in the inland zone. Apart from the alluvium in coastal and inland plains, the karstic springs located at the local boundaries between the carbonates and the impermeable Eocene-Miocene units are the major source of groundwater in the study area (e.g. Coskun 1978; Elhatib and Günay 1998). The low-to-moderate discharges (up to Qmean $=0.5 \mathrm{~m}^{3} / \mathrm{s}$ ) of inland karstic springs (e.g. Elhatib 1992) imply the presence of a significant karstic outflow toward the sea along the coastal zone. Part of the karst groundwater also feeds a few seasonal creeks that flow through the deeply trenched 


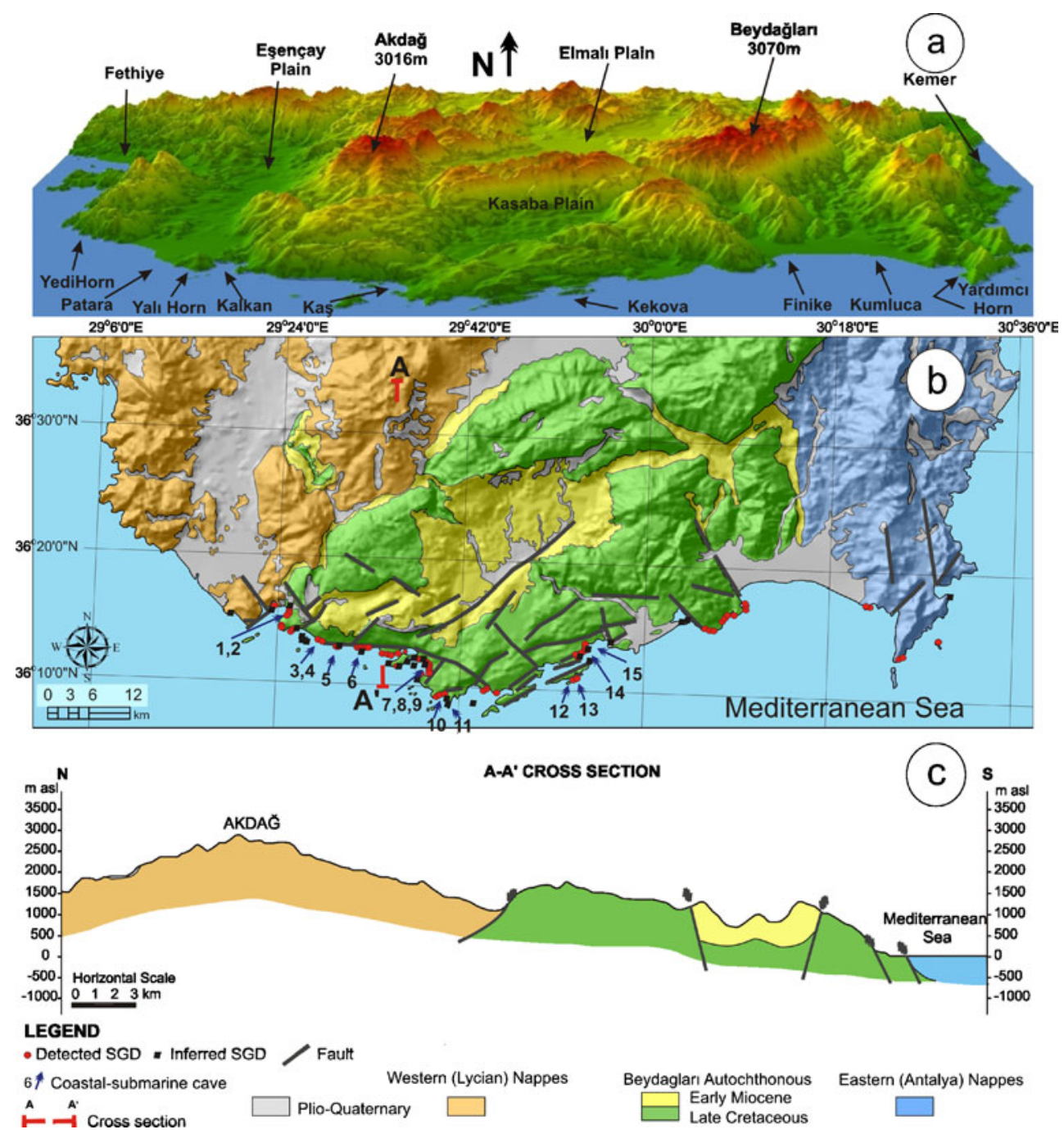

Fig. 2 a Digital elevation model, for which red indicates highest elevations and green lowest elevation; b simplified geologic map (see legend for explanation of colours), and $\mathbf{c}$ simplified geologic cross section of the study area

valleys of the carbonate terrain before discharging into the sea.

Geological structure implies that a great majority of karstic discharges through the SGDs in the study area should be supplied by the autochthonous carbonate rocks (see Fig. 2). Realistic calculation of the hydrologic budget in mountainous basins, like the study area, is difficult, mainly due to uneven distribution of meteorological observation stations (MOS). Throughout the recharge area, extending from sea level to more than $3,000 \mathrm{~m}$ asl, the mean annual bulk precipitation (MAP) ranges from $850 \mathrm{~mm}$ at sea level to $1,600 \mathrm{~mm}$ at elevations $1,000 \mathrm{~m}$ and over. Furthermore, meteorological observations do not exist for the elevations above $1,500 \mathrm{~m}$ where snowfall starts to dominate on a landform occupied mostly by naked karst. Under these circumstances, the MAP representing the entire recharge elevation range of the study area was assumed to be $950 \mathrm{~mm}$ based on experiences gained from similar karst basins in the Taurus Mountains range (e.g. Bayari 1986; Bayari 1991; Ozyurt 2008a). On the other hand, the chloride mass balance analyses between the precipitation and the groundwater in these basins also revealed effective precipitation rates (Per) varying from $80-75 \%$ of bulk precipitation (Pbulk). This finding has also been supported by the water budget analyses (e.g. Bayari 1991). Therefore, for an assumed bulk precipitation (Pbulk) of $950 \mathrm{~mm}$, an effective annual precipitation (Pnet) of $700 \mathrm{~mm}$ (i.e. Pnet $=$ Pbulk $\times$ Per) was assumed for the study area. The inferred surface catchment area of the carbonate aquifer $(A)$ is about 2,100 $\mathrm{km}^{2}$. Accordingly, a mean annual discharge (Qt) of 46.6 $\mathrm{m}^{3} / \mathrm{s}$ (i.e. $Q=A \times P n e t$ ) is estimated to occur from the karst aquifer. The long-term stream flowrate observations reveal a mean annual discharge of about $4 \mathrm{~m}^{3} / \mathrm{s}$ (Qstr) while the total discharge from karst springs inland is assumed to be $6.6 \mathrm{~m}^{3} / \mathrm{s}$ (Qspr; e.g. Coskun 1978; DSI 1974; Elhatib and Günay 1998; Elhatib 1992). Consequently, the mean annual SGD (Qsgd) along the coastal zone of karst aquifer is estimated to be around $36 \mathrm{~m}^{3} / \mathrm{s}(\mathrm{i}$. e. Qsdg $=$ Qt - Qstr - Qspr). This value corresponds to $360 \mathrm{~L} / \mathrm{s}$ of discharge per $\mathrm{km}$ of about $100-\mathrm{km}$-long coastal zone occupied by carbonate rocks. While this value has a 
large margin of error (e.g. up to $+/-50 \%$ due to uncertainties associated with the estimation of bulk and effective precipitation), it still provides an insight into the range of magnitude of the SGD in the study area.

\section{Data and methods}

This study utilized a variety of techniques for the determination of the SGD locations and their temporal dynamics. The Landsat-TM satellite thermal images (band 6) with $60 \mathrm{~m}$ spatial resolution belonging to the western (taken on 26 August 1987) and eastern (taken on 1 August 1990) parts of the study area have been used to determine the thermal anomaly sites along the coast. Limited cloud cover and the wide contrast between the mean temperatures of seawater (e.g. $25^{\circ} \mathrm{C}$ ) and the groundwater (e.g. $15^{\circ} \mathrm{C}$ ) that feed the SGDs are the main factors that favored the use of satellite images taken during the August period. The images have been enhanced for color contrast after the geometric and radiometric calibration stages. The same satellite images have also been used to determine the extent of lineaments (i.e. faults and major fractures) along the coastal zone. The topographic and geologic maps have been used to justify the presence of image-based lineaments. Because of the low spatial resolution of satellite data, the entire coastline was also investigated systematically during the period from August 2003 to July 2004 by means of SCUBA diving. For this purpose, three diving teams of two to three members surveyed the entire coastline for thermal and visual evidence of SGDs at different depth intervals (i.e. 0 to $-10 \mathrm{~m},-10$ to $-20 \mathrm{~m}$, and -20 to $-30 \mathrm{~m})$. Changes in water temperature and visual turbidity (i.e. halocline and/or thermocline) as sensed by divers have been regarded as the likely zones of SGDs where the low salinity freshwater and high salinity seawater is mixed. The water samples collected from these locations have been analyzed in a laboratory for specific conductance (SC, electrical conductivity normalized to $25^{\circ} \mathrm{C}$ ) to validate the presence of SGDs. To collect a water sample, pre-cleaned polyethylene bottles of $1.5-\mathrm{L}$ in size were used. Prior to sampling, the bottle was held upside down and filled completely with air by using the diver's spare regulator. Then, the bottle was turned up to displace the air with the water sample. The sampling time by this method took up to a few minutes depending on the local conditions. Locations of samples were determined by global positioning system (GPS) measurements taken in the boats that accompanied the diving teams. The SGDs in the form of coastal and submarine caves have also been investigated in detail by separate diving campaigns. The diver-penetrable coastal and submarine caves were mapped (Fig. 3) according to the British Cave Research Association (BCRA) classification (e.g. Day 2002), and water samples were collected in parts of the caves where the presence of SGD is suspected. The SGDs detected during the dry period (i.e. August 2003) were also sampled in the early wet period (i. e. November 2003) to determine the temporal changes in

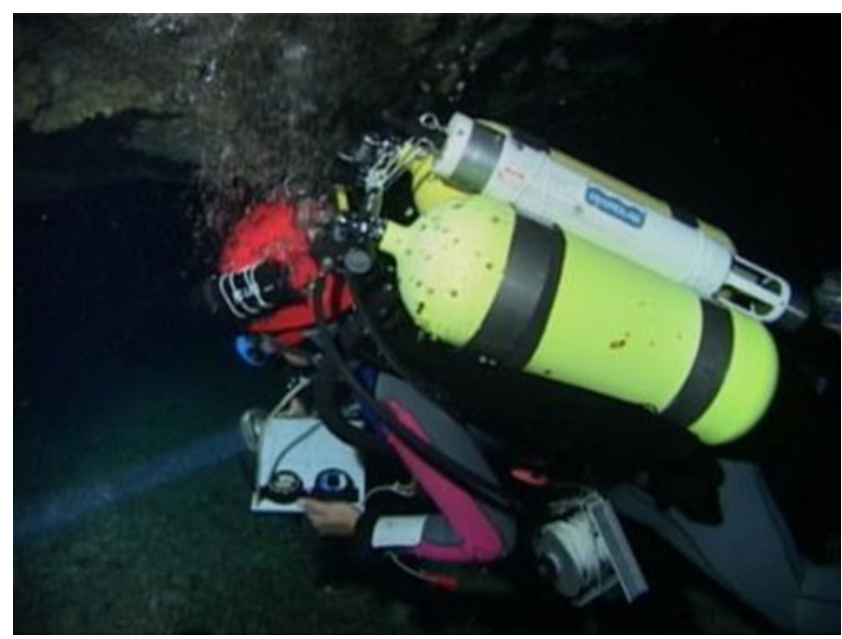

Fig. 3 Cave diver maps a submarine cave

groundwater outflow. In the study area, the wet period starts in November during which about $15-20 \%$ of total annual precipitation (i.e. $160-200 \mathrm{~mm} / \mathrm{month}$ ) falls. During these studies, typical samples that characterize the karst groundwater in the inland sector and the seawater $5 \mathrm{~km}$ offshore were also collected.

The water samples collected during the SCUBA surveying were analyzed for physical (SC), chemical ( $\mathrm{pH}$, major ions), isotopic (oxygen-18 $\left({ }^{18} \mathrm{O}\right)$, deuterium $\left({ }^{2} \mathrm{H}\right)$ and tritium $\left.\left({ }^{3} \mathrm{H}\right)\right)$ signatures. Major ion compositions of the samples were determined by ion chromatography (for $\mathrm{Ca}, \mathrm{Mg}, \mathrm{Sr}, \mathrm{Na}, \mathrm{K}, \mathrm{Li}, \mathrm{NH}_{4}, \mathrm{~F}, \mathrm{Br}, \mathrm{Cl}, \mathrm{SO}_{4}, \mathrm{PO}_{4}$, $\mathrm{NO}_{2}, \mathrm{NO}_{3}$ ) and by end-point titration (for $\mathrm{CO}_{3}, \mathrm{HCO}_{3}$ ) according to standard methods (i.e. APHA et al. 1989). The electro-neutrality values, as an indicator of the quality of analyses, are less than $+/-5 \%$. Total anion or cation contents of samples (in meq/l unit) multiplied by 100 approximate well with respective $\mathrm{SC}$ values. Stable isotope $\left({ }^{18} \mathrm{O}\right.$ and $\left.{ }^{2} \mathrm{H}\right)$ analyses of water samples were carried out by the International Atomic Energy Agency (IAEA) with an overall analytical uncertainty of $0.1 \%$ VSMOW (Vienna Standard Mean Ocean Water) for ${ }^{18} \mathrm{O}$ and $1.0 \%$ V-SMOW for ${ }^{2} \mathrm{H}$. The tritium $\left({ }^{3} \mathrm{H}\right)$ analyses were performed with respect to IAEA Dead Water $\left({ }^{3} \mathrm{H}=0\right.$ tritium units, TU) and NIST-SRM-4926E (National Institute of Standards and Technology, Standard Reference Material) by means of an ultra low-level-liquid-scintillation counting technique after alkaline electrolytic enrichment by electrolysis. All analyses were performed at the laboratories of Hacettepe University, except the stable isotopes, which were analyzed by the laboratories of the IAEA. The complete data set of 224 water samples is presented as electronic supplementary material (see Table 1 in ESM).

\section{Results and discussion}

\section{Spatial distribution of SGD sites}

Systematic diving surveys revealed the presence of 145 SGDs along the entire coastline of the study area. Many of 
the SGD spots are located in coves, which have been developed along fracture zones that form high hydraulicconductivity zones. SGDs along the coastal plains are observed only in the areas where the alluvium meets carbonate rocks (see Fig. 2). The alluvium forms productive aquifers with hydraulic gradients towards the sea (DSI 1974); detection of these aquifers along the coastline is difficult, probably because of the diffuse flow of the alluvial groundwater. The method of detecting SGDs in this study requires the presence of localized flow so that the temperature and salinity anomalies (i.e. thermocline and halocline) can be sensed by the diver.

Among all SGDs detected, only 15 of them are in the form of diver-penetrable coastal or submarine caves. Many of these caves are located on the western part of the coastline where fracture-controlled SGDs are also clustered. In general, the spatial distribution of SGDs is not always associated with the major fault zones that intersect the coastline. This shows that, while the major faults may have an important role in directing the inland groundwater flow towards the sea, the small-scale structural elements along the coastline have the final control in establishing the recharge of SGDs. It is also noted that many of the SGDs are located along the coastline where there is strong topographic gradient toward inland. The steeper topographic gradient appears to favor a steeper hydraulic gradient, which would cause more groundwater discharge toward the sea. Moreover, the areas located in front of the steeper topographic gradient are expected to receive more precipitation due to the orographic barrier effect. This would result in locally enhanced groundwater recharge that would result in formation of a greater number of SGDs with stronger outflows along the coastline.

A comparison of the SGD spots inferred from satellite data with those detected by divers reveals that the satellite data are incapable of inferring all of the existing SGDs. About half of the satellite-inferred spots do not include a SGD and about half of the detected SGDs are invisible on the satellite images (see Fig. 2). The low spatial resolution of satellite data is probably the major factor that limits its use in accurate detection of SGDs. Many of the SGDs detected by diving surveys have been found to have more limited spatial extent (e.g. 10-20 m) than the resolution of satellite images used $(60 \mathrm{~m})$. An analysis of the satellite images shows also that some other factors could cause false interpretation of the reflectance data. The thermal anomaly spots, particularly those observed offshore, appear to be associated with wind-induced evaporation which reduces the sea surface temperature (Fig. 4). Such areas are located mostly at the lee side of islands. A similar process may also occur along the coastline where the wavy coastline causes strong turbulent wind patterns. Furthermore, false thermal anomalies may also be caused by suspended matter (e.g. algae) floating on the sea surface.

On the other hand, the reason for the SGDs being missed in satellite data interpretation may be the temporal changes in the rate of outflow of the individual SGDs. For instance, some of the SGDs detected by divers in the early wet period (i.e. November) were not apparent in the dry period (e.g. August) surveys. This shows the importance of multi-temporal satellite data analyses for an accurate detection of SGD spots. Moreover, the performance of the satellite data in inferring the SGD spots may be linked with the aridity of the respective years (1987 and 1990). Based on available records, the annual precipitation values that occurred in $1987(297.7 \mathrm{~mm})$ and in $1990(243.5 \mathrm{~mm})$ are about 32 and $28 \%$ of the precipitation that occurred in $2003(876 \mathrm{~mm})$, respectively. The number of diverdetected SGDs in 2003 and the number of SGD spots missed in the images of 1987 and 1990 seem to be in agreement with the amount of precipitation that occurred in respective years. The previously mentioned evaluations reveal that the SGD spot estimates based on satellite data should be based on images taken in more humid years and/or seasons. Comparison of images taken in more humid and more arid times may be used as an indicator of the temporal sustainability of individual SGDs.

\section{Morphology of coastal and submarine caves}

From a morphological point of view, the SGDs in the form of coastal and submarine caves are characterized by four distinct extended profiles (Table 1; Fig. 5a-d). The "sea level" (SL) type caves, which exhibit a horizontal landward development from the coastline (Fig. 5a) are associated with the carbonate rock dissolution along the present sea level. Some of these caves with small volumes and entrances, located within the $9 \mathrm{~m}$ depth zone from the present sea level, are anticipated to have formed in the Quaternary when the global sea level dropped more than $100 \mathrm{~m}$ (e.g. Ford and Williams 1989, p. 427). The development of the "bathyphreatic" (BP) type caves are linked with the mixing corrosion (e.g. Bögli 1964) occurring along the three dimensionally complex extent of the fracture planes (Fig. 5b). The "seawater-freshwater interface" (SFI) type of the submarine caves possesses a quasi-linear development that starts slightly below the recent sea level and dips landward along the seawaterfreshwater interface (Fig. 5c). These caves are fed by deep groundwater flow systems as implied by their considerable bottom depths. The fourth, "submerged-epikarstic" (SE) type of submarine caves show a vertical development that starts at the sea bottom as a cylindrical shaft, which is connected to large collapse chambers at increasing depths (Fig. 5d). This type of cave appears to have developed in the unsaturated (epikarst) zone of the karst aquifer during the period(s) when the sea level was lower than present. Because the study area has been uplifted since the late Miocene, the lower sea level required for epikarstic cave development is likely to have occurred during the glacial periods of the Quaternary when the Mediterranean Sea level dropped more than $100 \mathrm{~m}$. However, part of the conduit systems feeding the current SGDs might have been developed during the geologic past that extends even to the Messinian salinity crisis, which occurred about 5 million years ago. Nevertheless, the reestablishment of new conduit networks may occur in a geologically short 


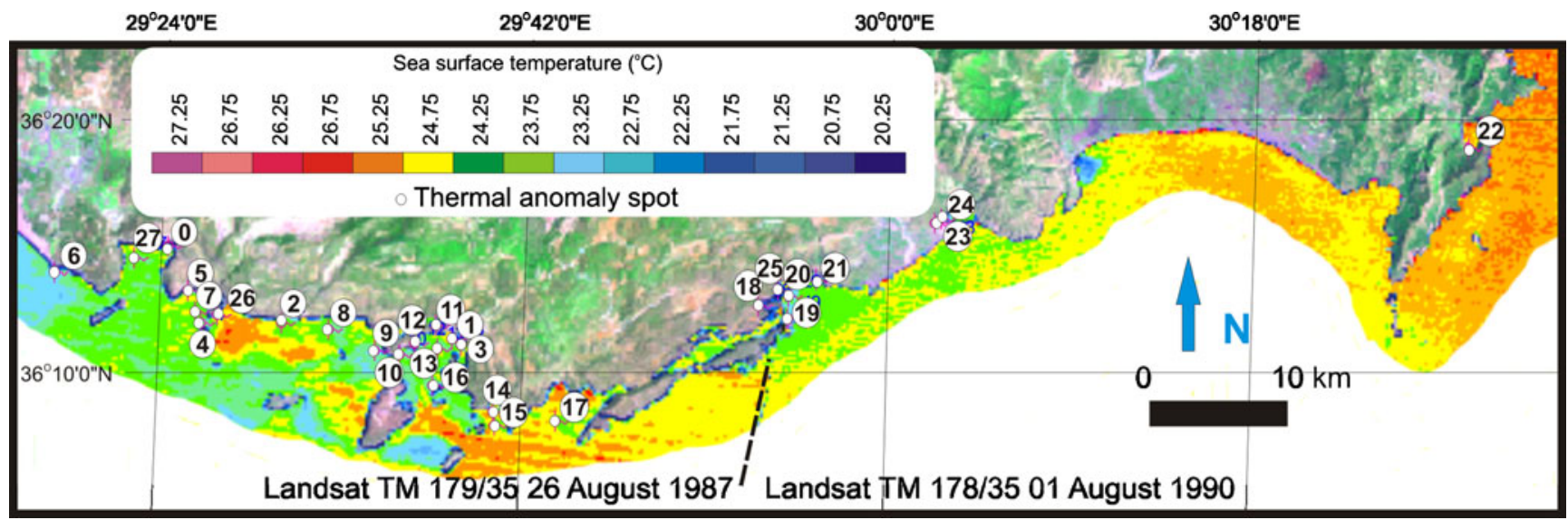

Fig. 4 Spatial distribution of the likely sites of SGDs as inferred from satellite images

period (in the order of several tens of thousands years, e.g. Dreybrodt 1990; Dreybrodt and Gabrovsek 2003; Kaufmann and Braun 2000). Therefore, the present conduit systems feeding the SGDs should have been shaped mostly in the recent geological past, though part of the older (i.e. inherited) networks still may have been used.

Currently, many of the coastal and submarine caves discharge freshwater (see Table 1) that is required for carbonate rock dissolution driven by the mixing corrosion (e.g. Bögli 1980; Back and Hanshaw 1971; Back and Freeze 1983). Geochemical modeling exercises, as explained later, reveal that more than $45 \%$ freshwater contribution to the SGD is required to sustain the cave development under the present conditions. The freshwater contribution rate of more than $45 \%$, as observed in many of the coastal and submarine caves (see Table 1), suggests an ongoing cave development.

\section{Hydrochemistry}

As expected from a carbonate-rock-dominated karst terrain, the typical freshwater end member (FEM) repre- senting the inland karst groundwater in the study area is represented by $\mathrm{Ca}-\mathrm{HCO}_{3}$ facies with typical $\mathrm{pH}$ and $\mathrm{SC}$ values of 7.24 and $330 \mu \mathrm{S} / \mathrm{cm}$, respectively (Table 2). Similar physical and chemical characteristics have been observed in other karst terrains throughout the Taurus Mountains range (e.g. Ozyurt and Bayari 2008; Hatipoglu et al. 2009). The $\mathrm{pH}$ of karst groundwater implies a flow system that receives carbondioxide from the root zone during recharge. On the other hand, the typical seawater end member (SEM) representing the offshore conditions where SGD contribution is practically impossible is characterized by $\mathrm{Na}-\mathrm{Cl}$ facies with $\mathrm{pH}$ and $\mathrm{SC}$ values of 8.23 and $50,000 \mu \mathrm{S} / \mathrm{cm}$, respectively. The $\mathrm{pH}$ of seawater is typical of a well-homogenized water body that is in equilibrium with atmospheric carbon dioxide.

The physical and chemical properties of the SGDs are distributed between the FEM and SEM. Accordingly, the SGD samples are scattered on the Piper diagram along a mixing line between the freshwater and seawater end members (Fig. 6). However, many of the SGDs are located around the SEM because of the ionic dominance of the seawater in the mixtures. A seawater contribution of

Table 1 Characteristic properties of coastal and submarine caves in the study area

\begin{tabular}{lllllll}
\hline SGD no. & Name & $\begin{array}{l}\text { Entrance depth } \\
(\mathrm{m} \mathrm{bsl})\end{array}$ & $\begin{array}{l}\text { Diver penetrable } \\
\text { bottom depth (m bsl) }\end{array}$ & $\begin{array}{l}\text { Development } \\
\text { type }\end{array}$ & $\begin{array}{l}\text { Minimum freshwater } \\
\text { content (\%) }\end{array}$ & $\begin{array}{l}\text { Maximum freshwater } \\
\text { content }(\%)\end{array}$ \\
\hline 1 & Patara Evleri & -1.2 & -2.0 & SL & 6 & 66 \\
2 & Komurluk & +2.0 & -2.0 & SL & 32 & 60 \\
3 & Doruk & -4.4 & -5.1 & SL & 20 & 56 \\
4 & Prenses & -40.0 & -40.0 & BP & 6 & 75 \\
5 & Yilan & 0.0 & -9.0 & SL & 12 & 73 \\
6 & Mivini & -3.5 & -80.0 & FSI & 6 & 76 \\
7 & Havali & -4.0 & -5.1 & SL & 7 & 56 \\
8 & Cakil & -1.0 & -5.0 & BP & 4 & 74 \\
9 & Likya Batigi & 0.0 & -2.5 & SL & 60 & 15 \\
10 & Altug & -12.0 & -63.5 & SE & 0 & 48 \\
11 & Fakdere & -2.0 & -2.5 & SL & 24 & 66 \\
12 & Fok & -9.0 & -9.0 & SL & 27 & 8 \\
13 & Buza & -11.5 & -20.0 & SE+SL & 64 & 65 \\
14 & Gokkaya & 0.0 & SL & 22 & 28 \\
15 & Ilker Kaptan & -1.6 & -1.5 & & \\
\hline
\end{tabular}

Explanation: For SGD numbers see Fig. 2. Abbreviations: bsl below the present mean sea level; $S L$ sea level; $B P$ bathyphreatic; FSI freshwater/seawater interface; $S E$ submerged epikarstic. Freshwater content is based on SC measurements in dry and early wet periods of 2003 and 2004 


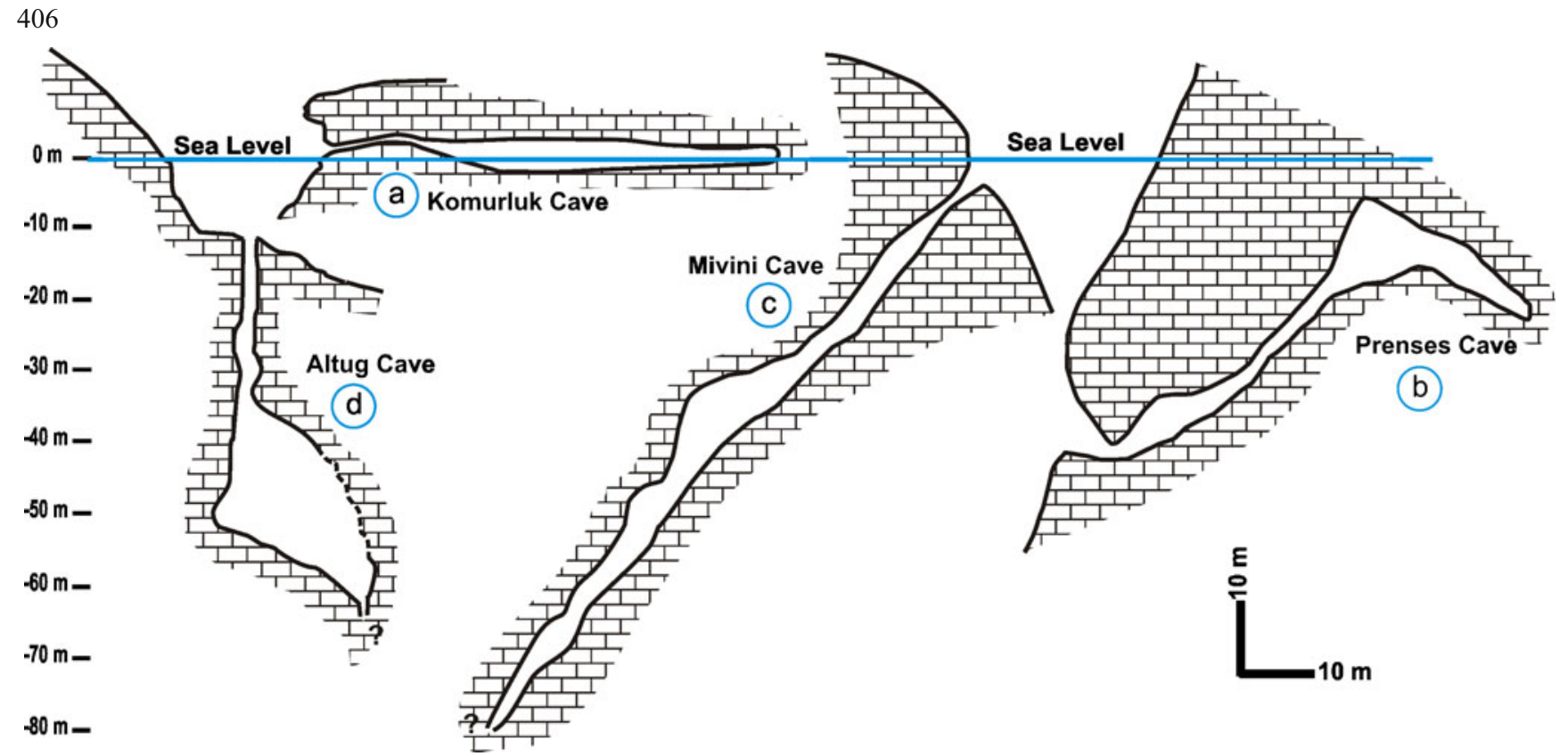

Fig. 5 Extended profiles showing the typical morphology of coastal and submarine caves in the study area. Cave types: a sea level (SL), b bathyphreatic (BP), c seawater-freshwater interface (SFI), d submerged-epikarstic (SE)

more than a few percent (i.e. $\mathrm{SC}>\sim 1,000 \mu \mathrm{S} / \mathrm{cm}$ ) is enough to convert a $\mathrm{Ca}-\mathrm{HCO}_{3}$-type freshwater into a $\mathrm{Na}-$ Cl-type saltwater.

The $\mathrm{pH}$ of the SGD samples collected in dry and early wet periods has a mean of $7.63(+/-0.27,1$ sigma standard deviation, SD) whereas the median value is slightly lower (7.56). As explained in the following sections, the carbonate rock dissolution due to mixing of FEM and SEM end members is the main factor that controls the variation of $\mathrm{pH}$ among SGDs (Fig. 7a). The SC of SGDs has the mean and median values of 31,622 and $33,000 \mu \mathrm{S} / \mathrm{cm}$, respectively. However, as seen in Fig. $7 \mathrm{~b}$, the SC of SGDs has a wide standard deviation range (about $+/-12,000 \mu \mathrm{S} / \mathrm{cm}, 1$ sigma $\mathrm{SD}$ ). The distribution of the SGD SC values between the FEM and SEM end members does not suggest a systematic trend.
Nevertheless, some of the SGDs appears to cluster around SC values of about 17,500, 30,000 and 42,500 $\mu \mathrm{S} / \mathrm{cm}$ (see zones I, II and III in Fig. 7b). The irregular variation of the SC of SGDs reveals a spatio-temporally variable groundwater outflow as can be expected from a coastline dominated by carbonate rocks with well-developed karst.

\section{Stable isotopes}

As in the case of chemical composition, the stable isotopic content of SGDs varies in a wide range (Fig. 8). The mean stable isotopic composition of inland groundwater (i.e. FEM) is characterized by ${ }^{18} \mathrm{O}$ and ${ }^{2} \mathrm{H}$ values of $-8.14 \%$ $\mathrm{V}-\mathrm{SMOW}$ and $-51.6 \% \mathrm{~V}-\mathrm{SMOW}$, respectively (see Table 2). On the other hand, the offshore seawater's (SEM) ${ }^{18} \mathrm{O}$ and ${ }^{2} \mathrm{H}$ compositions in the same period were

Table 2 Physical, chemical and isotopic characteristics of the typical end members of freshwater and seawater and, the statistics of SGDs for respective parameters

\begin{tabular}{|c|c|c|c|c|c|}
\hline Parameter & Unit & Typical freshwater & Typical seawater & SGDs mean & $\overline{\text { SGDs SD }}$ \\
\hline $\mathrm{pH}$ & - & 7.24 & 8.23 & 7.63 & 0.27 \\
\hline SC & $\mu \mathrm{S} / \mathrm{cm}$ & 320 & 50,000 & 31767 & 11,689 \\
\hline $\mathrm{Ca}$ & $\mathrm{meq} / \mathrm{l}$ & 1.56 & 26.08 & 18.55 & 8.12 \\
\hline $\mathrm{Mg}$ & $\mathrm{meq} / \mathrm{l}$ & 0.96 & 114.24 & 78.84 & 30.42 \\
\hline $\mathrm{Na}$ & $\mathrm{meq} / \mathrm{l}$ & 1.10 & 494.22 & 337.86 & 134.62 \\
\hline $\mathrm{K}$ & $\mathrm{meq} / \mathrm{l}$ & 0.04 & 10.72 & 7.85 & 3.39 \\
\hline $\mathrm{Cl}$ & $\mathrm{meq} / \mathrm{l}$ & 1.00 & 564.79 & 327.51 & 155.27 \\
\hline $\mathrm{SO}_{4}$ & meq/1 & 0.14 & 64.35 & 34.58 & 16.20 \\
\hline $\mathrm{CO}_{3}$ & $\mathrm{meq} / \mathrm{l}$ & 0.87 & 0.50 & 0.70 & 0.38 \\
\hline $\mathrm{HCO}_{3}$ & $\mathrm{meq} / 1$ & 1.22 & 3.17 & 2.27 & 0.68 \\
\hline${ }^{18} \mathrm{O}$ & $\%$ V-SMOW & -8.14 & 1.78 & -3.33 & 1.72 \\
\hline${ }^{2} \mathrm{H}$ & $\%$ V-SMOW & -51.60 & 11.75 & -17.30 & 11.03 \\
\hline${ }^{3} \mathrm{H}$ & TU & 4.27 & 0.89 & 1.83 & 1.05 \\
\hline${ }^{3} \mathrm{H}$ error & TU & 0.31 & 0.24 & 0.26 & 0.06 \\
\hline
\end{tabular}

Explanation: specific conductance (SC) is the electrical conductivity expressed for $25^{\circ} \mathrm{C} .{ }^{3} \mathrm{H}$ error indicates the mean of $+/-$ one sigma overall analytical uncertainty. $S D$ standard deviation 


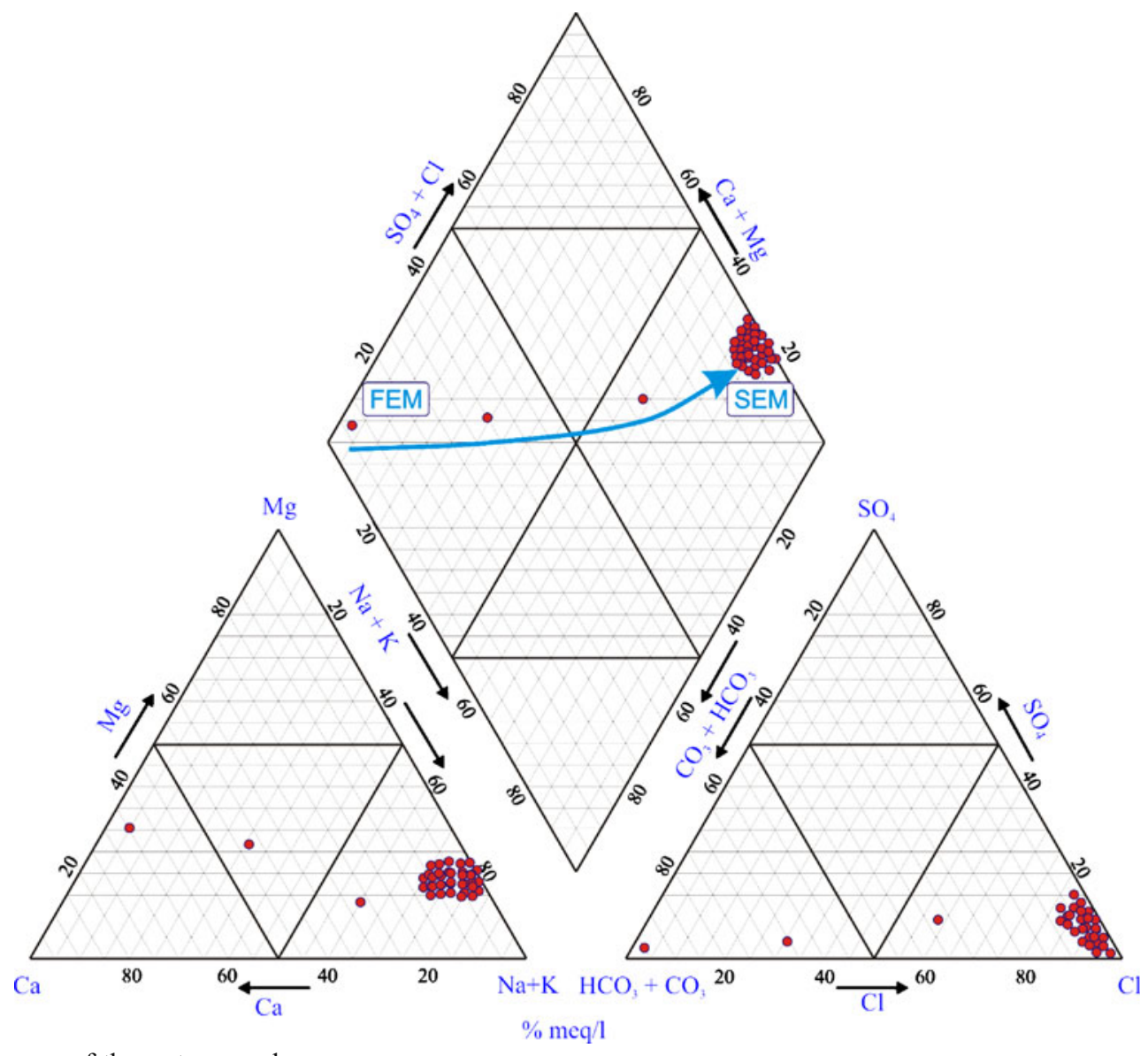

Fig. 6 Piper diagram of the water samples

found to be $+1.78 \%$ V-SMOW and $+11.75 \%$ V-SMOW, respectively. Another SEM sample collected in September 2003 revealed similar values (i.e. ${ }^{18} \mathrm{O}=+1.60 \%$ VSMOW, ${ }^{2} \mathrm{H}=+11.60 \%$ V-SMOW) within the overall analytical uncertainty of the measurements.

Previous studies (e.g. Yurtsever 1980; Elhatib and Günay 1998) reveal that the stable isotopic composition of both the inland groundwater and the local precipitation follow a local meteoric water line (LMWL) equation of $\delta^{2} H=8 \times \delta^{18} O+14.3$. The positions of the fresh groundwaters on the stable isotope scatter plot are in accordance with these observations (see Fig. 8). The SGDs are plotted along the hypothetical conservative mixing lines between the SEM and various FEMs. The FEM end member of the SGD samples collected in the early wet period have a wide range of FEM end member values with ${ }^{18} \mathrm{O}$ compositions ranging between ca. $-8 \%$ and ca. $-5 \%$ V-SMOW. However, many of the SGD samples collected in the dry period seem to be originated from the isotopically most depleted FEM.

The isotopic composition of monthly precipitation has been monitored at the Antalya meteorological station, located $120 \mathrm{~km}$ to the northeast of the study area, since the early 1960s. The long-term weighted mean annual ${ }^{18} \mathrm{O}$ composition of the precipitation observed at this station, which is located at $49 \mathrm{~m}$ asl, is $-5.36 \% \mathrm{~V}-\mathrm{SMOW}(+/-$ $0.57)$. An assessment of the annual precipitation's isotopic composition at various elevations throughout the western and central Taurus Mountains range by Yurtsever (1980) reveals an ${ }^{18} \mathrm{O}$ lapse rate of $-0.35 \%$ V-SMOW per $100-\mathrm{m}$ increase in elevation. A collective analysis of this information suggests a range of mean recharge area elevations of 6,578 and $1,149 \mathrm{~m}$ asl for the respective ${ }^{18} \mathrm{O}$ compositions of $-5,-7$ and $-9 \%$ V-SMOW for the various FEMs (see Fig. 8). However, it should be noted that the calculated elevations are based on selected ${ }^{18} \mathrm{O}$ compositions and the ${ }^{18} \mathrm{O}$ compositions of SGDs are usually time-variant due to varying mixing between FEM and SEM. The estimated elevation range appears to be in agreement with the existing topography and with the isotopic composition of SGDs belonging to Mivini and Prenses submarine caves (see Fig. 8). Because these caves have bottoms extending to relatively greater depths, they are likely to be fed by deep groundwater flow lines that originate from relatively high elevations where the precipitation is isotopically more depleted. The stable isotope signal of SGDs seems not be correlated with their entrance depths.

The scatter plot of ${ }^{18} \mathrm{O}$ versus specific conductance indicates that, for many of the SGDs, the stable isotopic composition $\left({ }^{18} \mathrm{O}\right)$ of freshwater ranges between -8 and 6\% V-SMOW (Fig. 9). Only a few of the SGDs appear to have freshwater end members with more enriched isotopic composition. In fact, this is an expected situation from a 

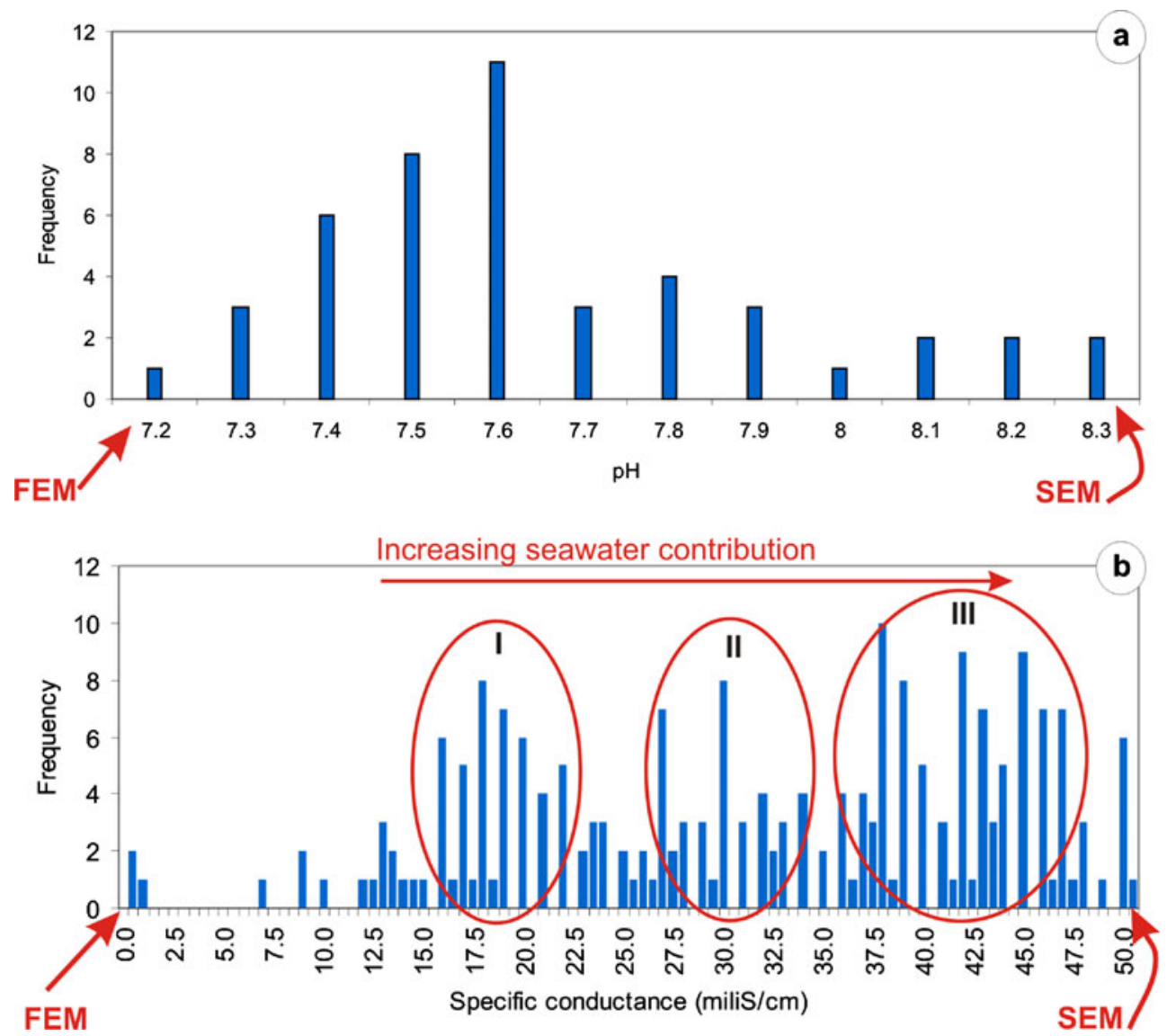

Fig. 7 Histograms of the observed $\mathbf{a} \mathrm{pH}$ and $\mathbf{b}$ specific conductance of the water samples

terrain with steep topographic gradient extending from coastline toward inland. In such a terrain, most of the orographic precipitation is expected to occur mostly at the moderate and high altitudes. The coastal zone receives precipitation mainly in months around winter when the air temperature is sufficiently low at this elevation. This figure implies that many of the SGD samples are fed by FEM end members for which the ${ }^{18} \mathrm{O}$ content varies between -8 and $-6 \%$ V-SMOW. Only a few samples seem to be fed by recharge occurring near sea level. The mean recharge area elevations of FEM end members inferred from the $\mathrm{SC}$ versus ${ }^{18} \mathrm{O}$ graph appears to be more informative when the topographic gradient variation in the study area is considered.

\section{Tritium}

The radioactive isotope of tritium $\left({ }^{3} \mathrm{H}\right)$, which is a part of the water molecule, is probably the best indicator of the groundwater's residence time. Briefly stated, the decreasing

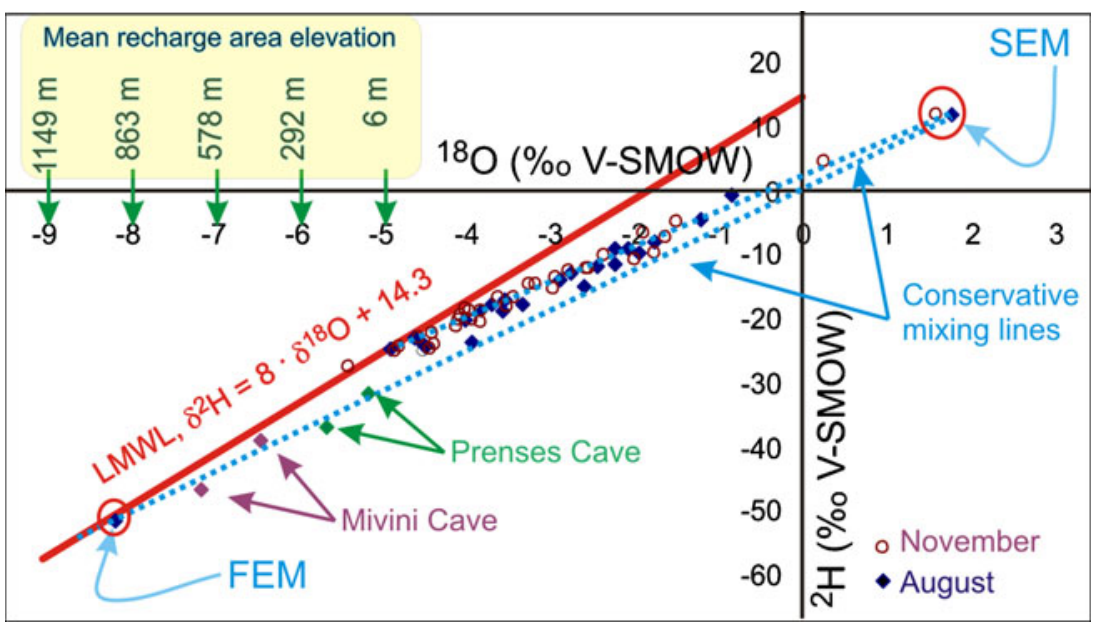

Fig. 8 Stable isotope scatter plot of water samples 


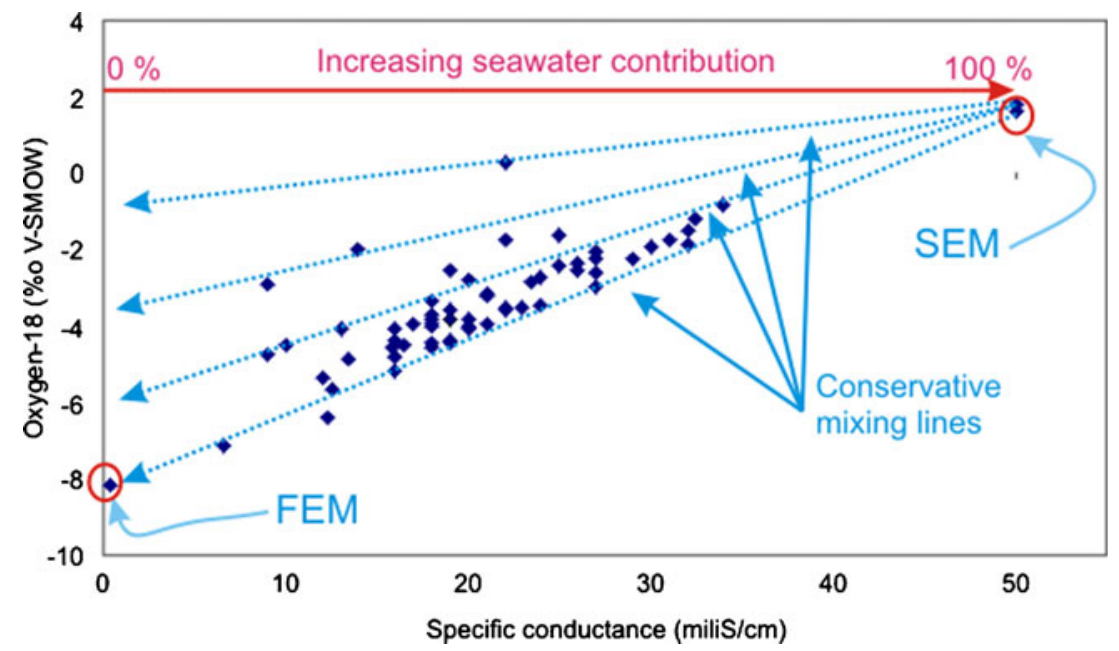

Fig. 9 The oxygen-18 versus specific conductance relationship of water samples

${ }^{3} \mathrm{H}$ content of groundwater indicates increasing residence time in the aquifer. Because of its conservative behavior in mixing processes, the ${ }^{3} \mathrm{H}$ content of the SGD may be used to infer the ${ }^{3} \mathrm{H}$ composition of the FEM end member if the ${ }^{3} \mathrm{H}$ content of the SEM end member is known. The ${ }^{3} \mathrm{H}$ content of SEM representing the dry and early wet periods is temporally stable around $0.9 \mathrm{TU}$ (see Table 2). On the other hand, the ${ }^{3} \mathrm{H}$ content of FEM samples belonging to dry and early wet periods show a temporally stable composition around 4.5 TU. The mean ${ }^{3} \mathrm{H}$ content of local precipitation during the last decade is very stable and has a value around 5 TU (e.g. Ozyurt 2008a).

The SC versus ${ }^{3} \mathrm{H}$ plot of water samples reveals that the ${ }^{3} \mathrm{H}$ content of SGDs is determined by the mixing between SEM and various FEMs (Fig. 10). The SGDs originating from relatively young FEMs (i.e. ${ }^{3} \mathrm{H}=3-5$ $\mathrm{TU}$ ) have a wide range of $\mathrm{SC}$ values that show a wide range of mixing between SEM and FEMs. On the other hand, the SGDs fed by FEMs with ${ }^{3} \mathrm{H}$ values between 0 and 2 TU have relatively low SC values (see Fig. 10). This suggests an increasing fresh groundwater contribution as the age of the FEM component increases. In general, the residence time of groundwater increases along with the increasing depth of flow routes for which the length of flow paths between the recharge and discharge areas are longer than those in the shallow part of the flow system. Therefore, the deeper flow routes in the study area appear to carry more freshwater compared to their shallow counterparts. This situation may be the result of enhanced dissolution due to mixing of freshwater with the seawater along the deep flow routes. Unlike the shallow counterparts, the deep flow routes (i.e. deep streamlines of groundwater) are in contact with the seawater that intrudes the aquifer. Both the seawater and the deep-circulating groundwater are expected to be in equilibrium with carbonate minerals. However, when both solutions with different temperatures and chemical compositions are mixed along the seawater-freshwater interface, they form a mixture which can be undersaturated with respect to carbonate minerals. Eventually, this mixture could result in rejuvenated dissolution (i.e. mixing corrosion) along this interface to form conduits, which dip from the sea surface towards inland. Compared to shallow circulation, the deep-circulating groundwater has a longer flow path

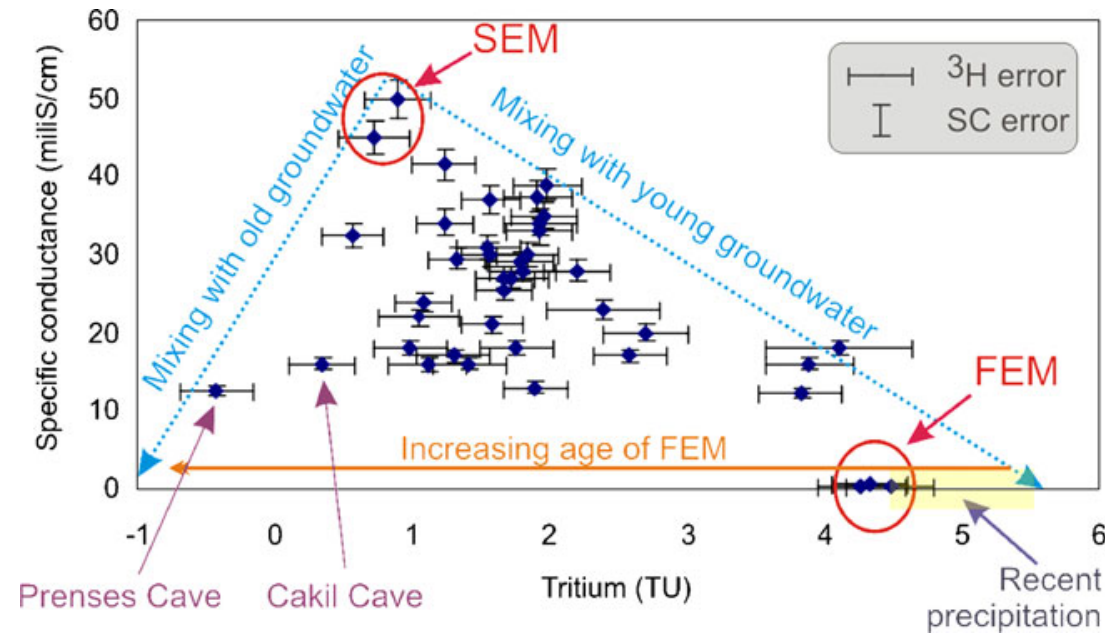

Fig. 10 The tritium versus specific conductance relationship of water samples 
and, thus, should have a greater residence time (e.g. Hatipoglu et al. 2009). The role of mixing corrosion in development of SGDs investigated is discussed in more detail in the section Conceptual hydrogeochemical model of karstic SGD development in the following.

The SGDs in the Prenses and Cakil caves appear to originate from FEMs with ${ }^{3} \mathrm{H}$ contents near to or below the IAEA dead-water blank used in the analyses. Therefore, these SGDs should be fed by the deepest flow routes that originate from the highest recharge elevation. A good example supporting this argument is the SGD discharging from Prenses cave where both the ${ }^{3} \mathrm{H}$ and stable isotope contents imply a deep flow system fed by high elevations (see Figs. 8 and 10).

The available ${ }^{3} \mathrm{H}$ data do not allow a robust estimate of the absolute ages of the FEMs feeding SGDs by means of numerical modeling (e.g. Ozyurt and Bayari 2005a, b). However, a recent modeling study in a neighboring basin revealed that a fresh karst groundwater end member with ${ }^{3} \mathrm{H}$ content around $5 \mathrm{TU}$ may have a mean residence time that is more than 100 years (e.g. Ozyurt 2008a). Groundwater age dating studies carried out in large-scale (i.e. $\sim 15,000-50,000 \mathrm{~km}^{2}$ ) inland karst basins of Turkey have shown that the groundwaters with negligible or without ${ }^{3} \mathrm{H}$ may have old water components for which model ages between 10,000 and 45,000 years are inferred (e.g. Bayari et al. 2009; Güner 2009). Therefore, a wide range of absolute groundwater ages for the FEMs associated with SGDs in the study seems likely. However, for many of the SGDs, the FEM ages are probably in the range of several tens to several hundred years. On the other hand, it should be noted that the previously mentioned statements are based on a simple assessment of limited data. A comprehensive assessment of the residence times of the freshwater end members requires periodic observations in the future years. Once longer data sets covering a period up to a decade are obtained, more robust residence time values can be obtained by means of the numerical analysis of the temporal tritium compositions of the seawater and precipitation. In a study carried out along the Syrian coast of the Mediterranean Sea Basin, Al Charideh (2007) suggests a tritium-based mean residence time of 60 years for Al-sen karst spring.

\section{Temporal variation of freshwater contribution rate}

The temporal change of the freshwater contribution rate $(\% \mathrm{Fw})$ in some of the SGDs selected for comparison has been determined for dry (August) and early wet (November) periods by using the SC of the SGD and the associated end members (FEM and SEM). While mixing between FEM and SEM in a SGD may cause carbonate mineral dissolution/precipitation, this process is assumed to be rather too slow to affect the ionic mass balance. A comparison of the freshwater contribution rates based on $\mathrm{SC}$ and ${ }^{18} \mathrm{O}$ content revealed similar results suggesting the validity of the previously mentioned assumption.

The magnitude of $\% \mathrm{Fw}$ in SGDs investigated has been determined by the following mass balance equation in which SC_SGD, SC_FEM and SC_SEM indicate the SC of SGD, FEM and SEM, respectively. In the $\% \mathrm{Fw}$ calculations, the SC_FEM $(300 \mu \mathrm{S} / \mathrm{cm})$ and SC_SEM $(50,000 \mu \mathrm{S} / \mathrm{cm})$ were assumed to be temporally invariant because slight changes (e.g. 10\%) that occur in different periods do not have an appreciable effect on the results.

$\% F w=\left[1-\frac{\left(S C \_S G D-S C \_F E M\right)}{\left(S C \_S E M-S C-F E M\right)}\right] \times 100$

The $\% \mathrm{Fw}$ in the SGDs investigated in dry and early wet periods ranges between $\sim 35 \%$ and $\sim 85 \%$ around a mean value of $\sim 60 \%$ (Fig. 11). Generally, the temporal variation of $\% \mathrm{Fw}$ among the SGDs investigated indicates an increase in the FEM contribution from the dry to early wet period when the recharge from precipitation starts. However, in some of the SGDs, the early wet period $\% \mathrm{Fw}$ does not show the same increase probably because these sites have not yet affected the recent recharge. Such sites are fed probably by the weakly developed fracture and/or conduit systems that do not allow fast transmission of the recharge.

An overview of the temporal variation reveals that the SGDs in the form of coastal or submarine caves have similar $\% \mathrm{Fw}$ in both periods. For example, the $\% \mathrm{Fw}$ variation in Prenses and Cakil caves, for which the isotope data imply freshwater contribution by deep flow systems, is close to or within the assumed analytical error of SC data. This is probably due to the fact that the deep flow systems have not yet been affected by the early wet period recharge. A similar situation is observed also in some of the facture-type SGDs while some others in the same class possess a high degree of $\% \mathrm{Fw}$ variation between the two periods. In many of the fracture-type SGDs, early wet period recharge causes $10-20 \%$ increase in the $\% \mathrm{Fw}$ rate. Such SGDs appear to be fed by well-developed fracture systems that ease the percolation of recent recharge. Additional observations of $\% \mathrm{Fw}$ have also been carried out in coastal and submarine SGDs in May 2004 and in September 2004 when the freshwater contribution rates are at maximum and minimum, respectively. These observations resulted in a wider range of $\% \mathrm{Fw}$ distribution between these periods. However, the previously mentioned assessments are based only on two single observations obtained in dry (August) and early wet (November) periods. More frequent observations in future studies will obviously provide a better picture of the temporal dynamics of the SGDs investigated. A comparison of the $\% \mathrm{Fw}$ data for the SGDs observed in both years reveals similar maximum $\% \mathrm{Fw}$ rates while the minimum $\%$ Fw rates differ substantially (see Table 1 and Fig. 11). This large difference is likely to be a result of lower net annual recharge in 2004 (632 mm/year) compared to 2003 (876 mm/year).

An assessment of the high temporal resolution (10 min) salinity and temperature observations carried out in Altug submarine cave for a period of about 1 year revealed that the freshwater contribution to this SGD is governed mainly by the precipitation recharge (Ozyurt 2008b). That study shows a steady decline of temperature and specific 


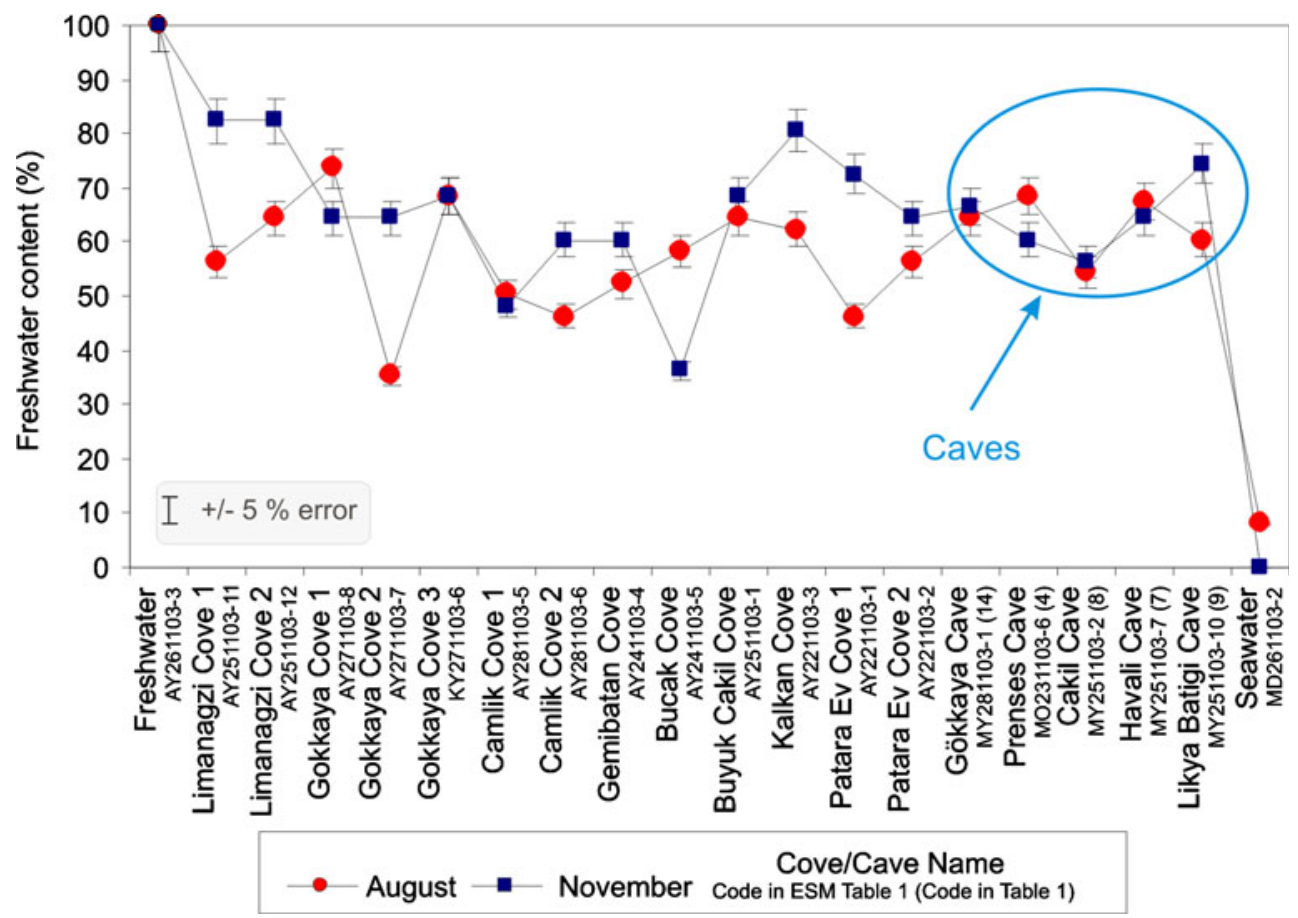

Fig. 11 Temporal variation of specific conductance-based freshwater discharge contribution in the selected SGDs

conductance during the period between late autumn and late spring because of the increasing weight of the wet period recharge. A steady increase in these parameters between the late spring and late summer, when recharge from precipitation is negligible, arises from the declining freshwater contribution into the SGD from this cave.

Eventually, the spatio-temporal variation of $\% \mathrm{Fw}$ in the SGDs investigated reveals a complex karst system whose response to recharge varies spatio-temporally. Some of the SGDs respond quickly to the early winter (November) precipitation, whereas, in some SGDs, several months of winter precipitation are required to increase the amount of the freshwater component. Such variations seem to be determined by the spatial variations of the degree of karstification and the temporal variations of the rate of precipitation.

\section{Conceptual hydrogeochemical model of karstic SGD development}

The PHREEQC software (Parkhurst 1995) has been used to assess the conditions that lead to the development of coastal and submarine caves in the study area. For this purpose, the freshwater and seawater end members have been mixed in various proportions to determine the varying degree of aggressivity of the mixture in dissolving calcite. In these calculations, the freshwater end member is assumed to be a pure water $\left(\mathrm{pH}=7.0\right.$, density $\left.=1 \mathrm{~g} / \mathrm{cm}^{3}\right)$ that is in equilibrium with calcite (SI cc $=0$, SI: saturation index for calcite) at a root zone atmospheric carbon dioxide partial pressure of $10^{-2} \mathrm{~atm}$. The seawater end member (density $=$ $1.023 \mathrm{~g} / \mathrm{cm}^{3}$ ) has been assumed to have a typical composition for the study area (see Table 2). The solutions have been mixed for freshwater contribution rates ranging between 10 and $90 \%$. The calculations have been made for three hypothetical sets of temperatures to represent the conditions during winter (seawater $15^{\circ} \mathrm{C}$, groundwater $15^{\circ} \mathrm{C}$ ), spring (seawater $25^{\circ} \mathrm{C}$, groundwater $15^{\circ} \mathrm{C}$ ) and summer (seawater $25^{\circ} \mathrm{C}$, groundwater $25^{\circ} \mathrm{C}$ ). The mean annual temperature of the freshwater end member is around $15^{\circ} \mathrm{C}$. However, to account for exceptional cases of extreme warming-up during the summer time due to contact with rocks at depths close to surface, a groundwater temperature of $25^{\circ} \mathrm{C}$ has also been included in the calculations. Based on field observations, the winter and summer seawater temperatures are assumed to be 15 and $25^{\circ} \mathrm{C}$, respectively. Among all temperature sets, those assumed to represent "winter" and "spring" conditions are more plausible then the one for "summer". In addition, effective dissolution is expected to occur during the winter and spring periods when the freshwater outflow is highest.

The saturation index of the solution, comprising of the "mixture" of SEM and FEM end members, with respect to calcite (SI_cc) can be used as a measure of the probability of submarine conduit/cave formation. In order for the solution to dissolve calcite, the SI cc must have a negative value (i.e. SI_cc $<0$ ). Therefore, the more negative the SI_cc, the higher the probability of calcite dissolution. In the case of SI cc $=0$, the solution is in equilibrium with calcite and for the case of SI_cc $>0$, it tends to precipitate calcite. However, numerous uncertainties such as impurity of calcite in carbonate rocks and analytical errors associated with the other variables used, affect the model-calculated SI_cc values. In many cases, estimation of the uncertainty associated with calculated SI_cc values is difficult to assess. Therefore, the calculated SI_cc values are assumed to have an overall uncertainty \pm 0.2 so that a mixture with a SI cc $\leq+0.2$ was assumed to be undersaturated with respect to calcite. 
The results of the modeling exercises show that the mixture becomes undersatured for calcite as the freshwater contribution rate exceeds $60 \%$ for all temperature sets considered (Fig. 12a). For the case of the winter temperature set, the mixture becomes aggressive to calcite if its freshwater-end-member-contribution rate exceeds $45 \%$. For the cases of spring and summer temperature sets, the contribution rate needs to exceed 50 and about $60 \%$, respectively. In other words, a conduit/cave would start to develop if more than $45 \% \mathrm{FEM}$ is involved in the mixture under cool (winter) conditions, while more FEM is required for dissolution under warmer (summer) conditions. Because the freshwater outflow is much greater during the winter and spring period, it seems very likely that much of the conduit/cave development occurs during these periods if the FEM in the mixture exceeds $45-55 \%$.

The results of the geochemical model calculations reveal also that the $\mathrm{pH}$ of the mixture should be around 7.6 or lower in order to sustain the calcite dissolution (Fig. 12b). The $\mathrm{pH}$ of the mixture appears to be less sensitive to the minimum freshwater contribution rate required for dissolution. In other words, a mixture $\mathrm{pH}$ of $\sim 7.6$ or lower would be required for calcite dissolution both under the winter and summer temperature conditions. However, the minimum freshwater contributions of $\sim 45$ and $\sim 60 \%$ would be required for the respective cases.

The previously mentioned deductions imply that the $\mathrm{pH}$ of a SGD can be used to infer the degree of current calcite dissolution because the $\mathrm{pH}$ is relatively insensitive to SGD temperature. Stated in other words, SGDs with $\mathrm{pH}$ values less than $\sim 7.6$ are very likely to have a calcite dissolution process. This threshold $\mathrm{pH}$ value $(\sim 7.6)$ corresponds also to the mean or median of the observed $\mathrm{pH}$ values of SGDs. This means, about half of the SGDs in the study area have been subject to ongoing conduit/ cave development during the study period. It is very likely that such a karst development is favored by the preexisting karst conduits.

A comparison of the measured $\mathrm{pH}$ and calculated SI_cc values of 11 water samples, representing SGDs with $\% \overline{\mathrm{F}} \mathrm{w}$ ratios ranging between 8 and $83 \%$, with the theoretical trends of these variables, shows a good match between the results of geochemical modeling exercises and the fieldbased data (see Fig. 12a and b). The discrepancies between the results of models and the field-based data are within the uncertainty limits of such calculations. Therefore, mixing corrosion appears to be an important process in development of the conduit systems associated with the SGDs investigated. Details of geochemical modeling exercises concerning the hypothetical and field-based data are presented as electronic supplementary material (see Tables 2-3 and Figure 1, ESM).

\section{Conclusions and outlook}

The results of this study reveal that the southwestern coast of Turkey involves about 150 SGDs, all of which are
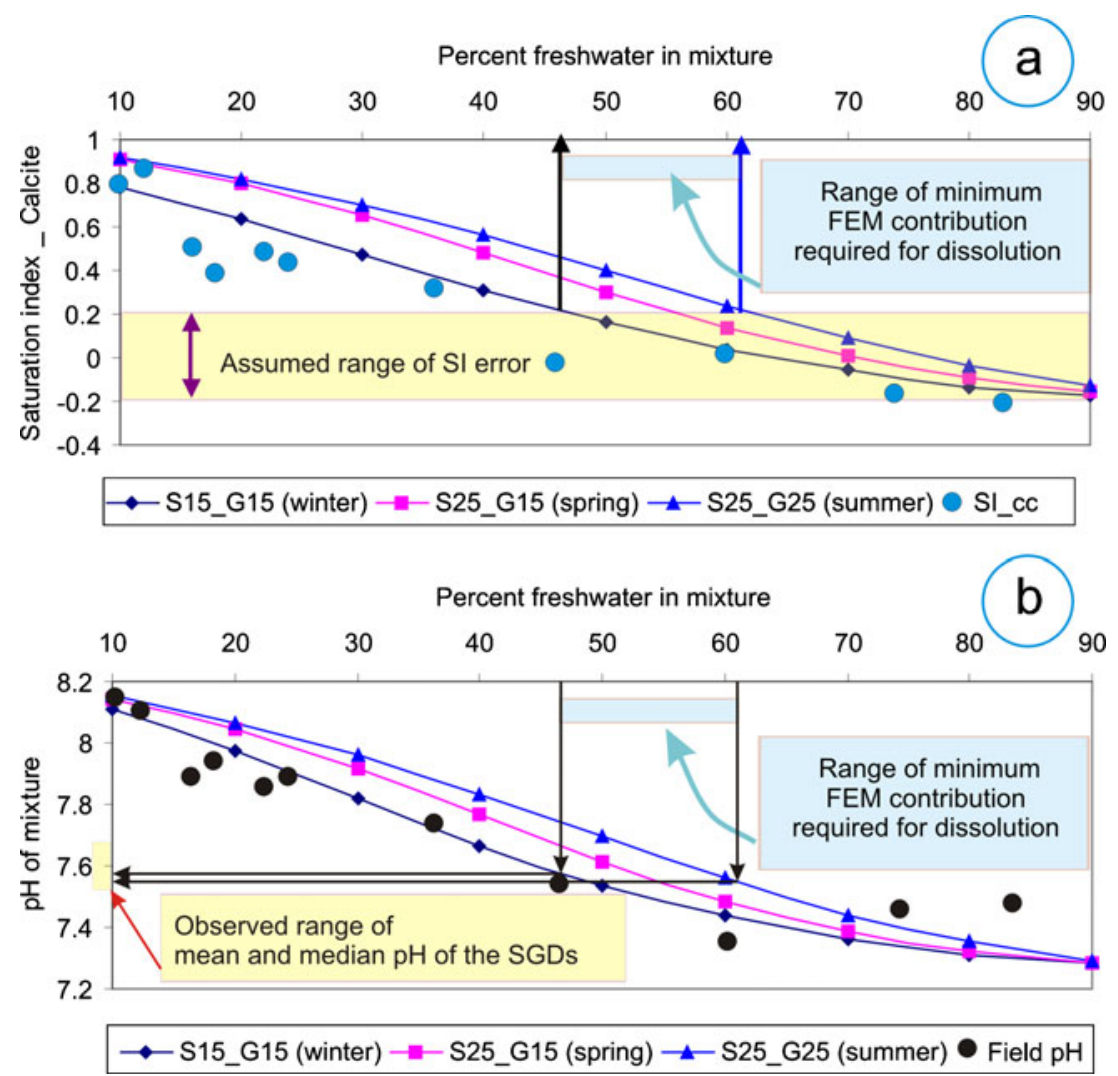

Fig. 12 Comparison of the calculated saturation index $\left(S I \_c\right)$ and field $p H$ with those calculated by the hypothetical geochemical model a for SI-cc and $\mathbf{b}$ for $\mathrm{pH}$ of the mixture, with respect to varying rates of freshwater contributions 
scattered along a $120 \mathrm{~km}$-long stretch of cliffs formed by carbonate rocks with well-developed karst. The ratio of freshwater end member among the SGDs investigated ranges from a few percent to more than $80 \%$. As in the case of many coastal karst aquifers, seasonal variations in the recharge rate during a hydrological year appear to be the main cause of freshwater flow rate variations, and consequently of mixing rate between seawater and freshwater. The main recharge area elevation of the freshwater end member feeding the SGDs range from the coastal zone to mountains located inland. The inferred ${ }^{3} \mathrm{H}$ content of the freshwater end member indicates residence times ranging from recent to several decades, while groundwater residence times more than hundreds of years have also been inferred in several SGDs.

This study highlights the importance of a multidisciplinary approach in the SGD investigations. Systematic field surveys by diving teams looking for temperature and turbidity anomalies seem to be the most effective in detecting SGDs. Such surveys should be carried out during the period when the thermal contrast between the freshwater and seawater end members is at a maximum. Thermal anomaly data obtained from satellite images may be used to detect SGD sites if their spatial extent is large enough to fit into the spatial resolution of satellite sensors. It seems that a survey of the seawater's temperature, SC, $\mathrm{pH}$ and turbidity by means of an instrument towed by a boat along the coastline is a faster alternative to detecting the SGDs. However, this method may be difficult to employ in wavy coastal zones with irregular bottom topography. While submarines (remotely operated vehicles, ROVs) can circumvent this problem, the survey time would be much longer than the sensor towing technique.

Hypothetical geochemical calculations of mixing between freshwater and seawater end members may help to predetermine the potential spots of submarine caves when supplemented with the seawater's $\mathrm{pH}$ data. Spots with $\mathrm{pH}$ values lower than the predetermined threshold $\mathrm{pH}$ may be the likely sites of submarine caves. However, the SGDs in the form of submarine caves may not involve detectable physical or chemical anomalies at all times of the year. In this case, visual observation by divers or by ROVs remains the only alternative in detecting submarine caves.

The simple SC measurement is probably the best costeffective way to validate the presence of SGDs at suspected sites. Submersible data loggers with temperature and SC sensors would also be economic ways to collect data on the temporal dynamics of SGDs. Finally, the isotope data $\left({ }^{18} \mathrm{O},{ }^{2} \mathrm{H}\right.$ and $\left.{ }^{3} \mathrm{H}\right)$ seem to be essential, particularly for characterizing the freshwater end member of the SGDs.

Acknowledgements Financial support to this study has been provided by the TUBITAK under the grant CAYDAG 103 Y025 and by the IAEA under the grant RC 12570. Divers of SADMADAG (Underwater Research Society-Cave Research and Diving Group, Ankara-Turkey) and ODTU-SAT (Middle East Technical University-Underwater Society, Ankara-Turkey) performed the
SCUBA surveys. We thank Dr. Bakalowicz and an anonymous reviewer for their critical comments, which helped to improve the manuscript.

\section{References}

Al Charideh AR (2007) Environmental isotopic and hydrochemical study of water in the karst aquifer and submarine springs of the Syrian coast. Hydrogeol J 15:351-364

APHA AWWA, WPCF (1989) Standard methods for the analysis of water and wastewater, 17th edn. APHA, Washington, DC

Back W, Freeze RA (1983) Chemical hydrogeology. In: Benchmark Papers in Geology, vol 73. Hutchinson Ross, Stroudsburg, PA, $416 \mathrm{pp}$

Back W, Hanshaw BB (1971) Rates of physical and chemical processes in a carbonate aquifer. In: Hem JD (ed) Nonequilibrium systems in natural water chemistry. Advances in Chemistry series, no. 106. American Chemical Society, Washington, DC, pp 77-93

Bakalowicz M, El Hakim M, El-Hajj A (2008) Karst groundwater resources in the countries of eastern Mediterranean: the example of Lebanon. Environ Geol 54:597-604

Bayari CS (1986) Karst hydrogeological investigation of the Upper Esencay Basin (in Turkish). MSc Thesis, Hacettepe University Institute of Pure and Applied Sciences, Turkey, $363 \mathrm{pp}$

Bayari CS (1991) Karst hydrogeological investigation of the Lower Zamanti Basin (Aladaglar) (in Turkish). PhD Thesis, Hacettepe University Institute of Pure and Applied Sciences, Turkey, 245 pp)

Bayari CS, Kurttas T (2002) Coastal and submarine karstic discharges in the Gökova Bay, SW Turkey. Q J Eng Geol Hydrogeol 35:381-390

Bayari CS, Ozyurt NN, Hamarat S, Bastanlar Y, Varinlioglu G (2007) Recovery of fresh water discharges along Turkish coast: Patara-Tekirova Pilot Project (in Turkish). TUBITAK Project report no. CAYDAG-103Y025, Ankara, Turkey

Bayari CS, Ozyurt NN, Kilani S (2009) Radiocarbon age distribution of groundwater in the Konya Closed Basin, central Anatolia, Turkey. Hydrogeol J 17:347-365

Bögli A (1964) Mischungskorrosion: ein Beitrag zum Verkarstungsproblem [Mixture corrosion: a contribution to the karst problem]. Erdkunde 18:83-92

Bögli A (1980) Karst hydrology and physical speleology, Springer, Heidelberg, $286 \mathrm{pp}$

Burnett TM, Cable JE Turner JV WC (2002) Investigation of submarine groundwater discharge. Hydrol Proc 16:2115-2129

Burnett WC, Aggarwal PK, Aureli A, Bokuniewicz H, Cable JE, Charette MA, Kontar E, Krupa S, Kulkarni KM, Loveless A, Moore WS, Oberdorfer JA, Oliveira J, Ozyurt NN, Povinec P, Privitera AMG, Rajar R, Ramessur RT, Scholten J, Stieglitz T, Taniguchi M, Turner JV (2006) Quantifying submarine groundwater discharge in the coastal zone via multiple methods. Sci Total Environ 367:498-543

Coskun N (1978) Hydrogeologic investigation report of the Antalya-Kas-Kalkan Town (in Turkish). DSI open file report, DSI, Ankara, Turkey, 23 pp

Day A (2002) Cave surveying. Cave Studies Series 11. British Cave Research Assoc., Buxton, UK, 40 pp

Dreybrodt W (1990) The role of dissolution kinetics in the development of karstification in limestone: a model simulation of karst evolution. J Geol 98:639-655

Dreybrodt W, Gabrovsek F (2003) Basic processes and mechanisms governing the evolution of karst. In: Gabrovsek F (ed) (2002) Evolution of karst: from prekarst to cessation. Zalozba ZRC, Postojna-Ljubljana, Slovenia, pp 115-154

DSI (1974) Hydrogeological investigation report of the FinikeKumluca Region (in Turkish). Open file report, DSI, Ankara, Turkey, $35 \mathrm{pp}$

Elhatib $H$ (1987) Hydrogeological investigation of the Ovacik submarine springs by means of remote sensing technique. MSc Thesis, Hacettepe University Ankara, Turkey 
Elhatib H (1992) Hydrogeological investigation of Kas-Kalkan Area and its vicinity. PhD Thesis, Hacettepe University Ankara, Turkey

Elhatib H, Günay G (1998) Karst hydrogeology of the Kas-Kalkan area. Environ Geol 36(1-2):150-158

Fleury P, Bakalowicz P, de Marsily G (2007) Submarine springs and coastal karst aquifers: a review. J Hydrol 339:79-92

Ford D, Williams P (1989) Karst geomorphology and hydrology. Chapman and Hall, London, $601 \mathrm{pp}$

Günay G (1971) Determination of the origin of Ovacik submarine springs by means of natural isotopes. IAH Reunion de Tokyo, Mémoires tome 9, pp 136-139

Güner IN (2009) Investigation of groundwater residence time distribution in the Upper Sakarya Basin by means of environmental tracers (in Turkish). PhD Thesis, Hacettepe University Ankara, Turkey

Hamarat S, Ulkenli H, Türe G, Bayari CS (1998) Investigation of the coast of Turkey: coastal caves of Aydicik-Tasucu (in Turkish). Book of proceedings, 2nd National Conference on the Management of Coastal Areas of Turkey, Ankara, September 1998, pp 81-90

Hatipoglu Z, Motz L, Bayari CS (2009) Characterization of the groundwater flow system in the hillside and coastal aquifers of the Mersin-Tarsus region (Turkey). Hydrogeol J 17:1761-1778

Kaufmann G, Braun J (2000) Karst aquifer evolution in fractured, porous rocks. Water Resour Res 36:1381-1391

Kazemi GA (2008) Editor's message: Submarine groundwater discharge studies and the absence of hydrogeologists. Hydrogeol J 16:201-204

Kohout FA (1966) Submarine springs: a neglected phenomenon of coastal hydrology. J Hydrol 26:391-413

Kohout FA (1977) Coastal and submarine springs of the Mediterranean Coast of Turkey. DSI technical report no. 15, DSI, Ankara, Turkey

Meric E, Avsar N, Yokes MB, Tugrul AB, Bayari CS, Ozyurt NN, Barut IF, Balkis N, Uysal B, Kam E (2008) Morphological abnormalities in benthic foraminifers of the Antalya coast. Micropaleontology 54(3-4):241-276

Mijatovic B (2007) The groundwater discharge in the Mediterranean karst coastal zones and freshwater tapping: set problems and adopted solutions. Environ Geol 51(5):737-742

Moore WS (1996) Large groundwater inputs to coastal waters revealed by Ra-226 enrichments. Nature 380:612-614

Oztan M (2004) Hydrogeological investigation of the coastal and submarine karstic discharges between Kalkan and Kekova (SW Turkey) (in Turkish). MSc Thesis, Hacettepe University Ankara, Turkey
Oztan M, Bastanlar Y, Varinlioglu G, Hamarat S, Ulkenli H, Ozyurt NN, Bayari CS (2004) Investigation of the Patara-Kekova freshwater discharges and the coastal and submarine caves (in Turkish). Book of proceedings, vol 2, Turkish Coasts 04, 4th National Conference on the Management of Coastal Areas of Turkey, 4-7 May 2004, Adana, Turkey, pp 815-824

Ozyurt NN (2008a) Residence time distribution in the Kirkgoz karst springs (Antalya- Turkey) as a tool for contamination vulnerability assessment. Environ Geol 53(7):1571-1583

Ozyurt NN (2008b) Analysis of drivers governing temporal salinity and temperature variations in groundwater discharge from Altug Submarine Karst Cave (Kas-Turkey). Environ Geol 54:731-736

Ozyurt NN, Bayari CS (2005a) Steady and unsteady state lumped parameter modeling of $3 \mathrm{H}$ and CFCs transport: hypothetical analyses and application to an alpine karst aquifer. Hydrol Proc 19(17):3269-3284

Ozyurt NN, Bayari CS (2005b) LUMPED Unsteady: a visual basic code of unsteady-state lumped-parameter models for residence time distribution analyses of groundwater systems. Comput Geosci 31(3):329-341

Ozyurt NN, Bayari CS (2008) Temporal variation of chemical and isotopic signals in major discharges of an Alpine karst aquifer in Turkey: implications with respect to response of karst aquifers to recharge. Hydrogeol J 16:297-309

Parkhurst DL (1995) User's guide to PHREEQC: a computer program for speciation, Reaction-path, Advective-transport, and Inverse Geochemical Calculations. US Geol Surv Water Resour Invest Rep 95-4227, 143 pp

SCOR and LOICZ (2006) Submarine groundwater discharge. UNESCO IHP-VI Series on Groundwater no. 5, IOC Manuals and Guides no. 44, UNESCO, Paris

Senel M (1997a) Fethiye Plate, 1/25,0000 scale geological maps of Turkey (in Turkish). MTA, Ankara, Turkey, $26 \mathrm{pp}$

Senel M (1997b) Antalya Plate, 1/25,0000 scale geological maps of Turkey (in Turkish). MTA, Ankara, Turkey, $25 \mathrm{pp}$

Taniguchi M, Burnett WC, Cable JE, Turner JV (2002) Investigation of submarine groundwater discharge. Hydrol Proc $16: 2115-2129$

Younger PL (1996) Submarine groundwater discharge. Nature 382:121-122

Yurtsever Y (1980) Environmental isotopes as a tool in hydrogeological investigations of southern karst regions of Turkey. In: Günay $\mathrm{G}$ (ed) Proceedings of the International Seminar on Karst Hydrology. DSI-UNDP, Oymapinar, Turkey, pp 269-293 